\title{
Atalanta Jolts Free
}

\author{
Carolyn Redl-Hlus
}

\section{Atalanta se libère}

Dans cette reécriture du mythe classique, Atalanta court dans le marathon relais Jasper-Banff avec une équipe de femmes. À cause d'une aventure avec Chasquis, le frère de Dionysus, elle les fait perdre la course. En le faisant, Atalanta, le sujet romanesque, se libère du sujet écrivant, et fait chavirer son projet d'écriture, un livre Relais.

It happened today, at precisely 2:48 -2:48 in the p.m. - that is, and dear knows, how many more months I would have been condemned to isolation in that dismal region of her brain, if it hadn't happened then. Who knows what actually prompted the jolt, but the moment Linschi, that's whose brain I've been locked tightly in for months now, Linschi's brain, the brain of my author, dear knows why it happened, but the moment she came barrelling through the back exit of the Humanities Centre at the University of Alberta where she teaches and works on her Ph.D., hardly paying attention to what she was doing, opening the door with a flourish, almost sweeping into the pavement one unsuspecting, loitering student, he, too, meaning to use the door, but from the other side, she thought, 'Atalanta!'

Just like that, 'Atalanta!' My name came to her.

There I was, out in the open again. Free of those musty, confining brain cells. Subjectified. Nominalized. Normalized. I can't describe the relief. Picture yourself, not only a runner, but a runner of mythological reputation, of some international success, and stuck tight in an author's subconscious. I was oppressed, utterly oppressed and, quite frankly, beginning to wonder if I would ever race again. Well. Now I'm free, and she has to figure out what she's going to do with me. Let me tell you, after all those lonely days and lonely nights, I won't give Linschi an iota of help. She's got to create the scenery, the allegory, the plot. I'll give myself up in total commitment, once she's figured out 
the entire scenario. After all, I have my honor to uphold. I am Atalanta. Simple as that. The absolute essence of one particular subject. Not without certain connotations, of course. I grant you liberty with my past, but what tickles my fancy is the future, the future Linschi may now pattern for me.

That Linschi. I could tell you a thing or two about her. She's put me in stories before. Good stories, too. At least, they had potential. But she's such a hopeless author. She lacks dedication. She'll write gripping first drafts, but the style always needs improvement. She has this thing about alternating jerky, short sentences with long, long run-on sentences. If she'd only make revisions and concentrate on how all the parts fit together to make up the whole, publishers might accept her work. She wouldn't have to bear the disappointment of rejection slip after rejection slip. After all, she has me, a fantastic subject.

Also, there's another problem. She is so easily side-tracked. Men are her demise. I begin to gain faith in her, begin to hope I'll feel the earth passing quickly underfoot, another race plotted for Atalanta, and she ... what does she do? She falls in love. It's happened more than once, and, I tell you, I am fed up with her shinannigans. This time, I will not permit her so much as a glance at a man until she takes me through my adventures.

Actually, Linschi has given me a fair share of liaisons. For example: I was the main character of her third unpublished novel, Relay. A plausible role, I might add. Oh, the glory! Leader of a coven of women runners pledged to win the women's trophy in the Jasper-Banff Relay, that seventeen-stage race from Jasper to Banff, Alberta, raced on the Icefields Parkway. A one hundred and eighty mile course. What a superb team. We did alright, too, up to a point. We did not win, but we pulled out all the stoppers and spread our wings. I admit, our loss was my fault. Linschi gave me a libido in that novel. I have to confess. Linschi set me up for disaster. Oh, I shouldn't put all the blame on her.

The women raced like mule deer on sighting a mountain meadow of fresh green hay.

You'd be interested in knowing, we were an impressive bunch. I won't list all our names. Just a few: Nellie McClung. Emily Murphy. Betty Friedan. All of us, upfront women.

I drew Stage Six and, by the time I started, we were already many minutes ahead of the next all-women's team, like us, contending for the women's trophy. As anyone who has run the Jasper-Banff Relay 
can attest, Stage Six, with its long, long hill, its mountain, up to the Columbia Icefields Restaurant and Gas Station, that stage is Hell. I finished it in good time. Feelin' groovy. Jubilant!

The relay has seventeen stages, as I said, and we had only thirteen runners, so some of us simply had to run two stages. Honorable leader that I am, I volunteered to run a second stage. Stage Fifteen. An easy stage, near the end of the relay.

I hesitate to tell you what happened between Stage Six and Stage Fifteen. In the middle of the night. I am terribly embarrassed, but I will reveal that certain other subjects were involved:

1) a tent;

2) Atalanta; and

3) Chasquis, lead runner of the Men's Rocky Mountain Elite Class A team and twin brother to Dionysus.

Poor Linschi! She could not save me from my fate. As a protagonist I failed her completely. She lost control and I, well, the plot went berserk. The book, Relay, was a disaster. Shortly after my little episode in the tent, Linschi herself had the audacity to fall in love with an expatriate Polish prince. You can imagine where that left me. In time, Chasquis had other races to run and the Polish prince deceived Linschi. We both sankinto those familiar post-affair depressions and I was lodged deep in the darkest caverns of the brain.

I should not complain. You see, I have had other authors, and some very prominent authors, too. Some have published very successful works. Most recently, with the rising interest in feminism, I've often been torn between authors, two or more at the same time, wanting to pattern characters after me, wanting to actually possess me in their fiction. For a time, in an early draft, Aritha van Herk had me in her novel, Judith. Linschi and Aritha actually discussed my significance over coffee one day. Envisioned possibilities. At any rate, Circe became Aritha's controlling figure. Her subject, so to speak. Circe has an easier time of it than me, what with weaving the destinies of men. Transforming men into pigs. Circe simply overdoes it, in my estimation, and I've told her so, too, but, then, you know my weakness. Well.

I wish I had time to tell you about the thousands and thousands of brains I've inhabited. The brains of women writers the world over. Each time, it's the same old story. Over and over again it's the apple the golden apple taking us down down stripping us of subjectivity 
claiming us as objects as part of some other deprived of total identity oh oh. I've tried and tried to overcome temptation. I know several of my authors have even taken the vow.

Desire wins. Heaven help me. Heaven help Linschi. Heaven help women writers everywhere.

Right now, I'm wandering through the rooms of Linschi's head. Cleaning my shoes on the edges of her teeth. Sliding down her tonsils. Climbing the old Eustachian tubes and into the cochlea. I will resist banishment at all costs. Charge onward with all defences up. This time, Linschi must weave me into a story that sells. I can hardly wait to experience the plot she imagines.

I'm perfectly aware of my place. Linschi has written five excellent stories tracing the experiences of a thirty-five year old woman, Semele. Mother of Daphne, age five. Time of the novel: the late 1980s. Place: Edmonton, Alberta. The essence of these stories seeps through forbidden membranes and into my cell. You may find this hard to believe, but I've been paying close attention to the liberties Linschi permits Semele. At this very moment, Semele is desperate. Desperately horny. Yes. You see, Semele has been divorced for two years and Linschi has not allowed her the pleasure of even one indiscretion. I know it's complicated with a daughter who still needs a sitter, but you'd think she could have given her, well, even an afternoon quickie. Oh, they are perfectly good stories, Linschi's stories about Semele. They break a reader's heart. They make a reader laugh. But they do not satisfy Semele's most subtle hunger. I know if Linschi could appropriate my subject for Semele, simply for an afternoon, I would change all that and bring a smile to Semele's face. Why not?

I suppose you're thinking that Linschi would not want Semele to mess around with the likes of me. Atalanta of the Golden Apple. All that stuff.

Semele is not the virtuous wonder you may take her to be. This all happened a long time ago back in Athens and, I suppose, I should not be bringing it up, after all these years. However, I will never forgive. Books never mention who it was tempted me with the Golden Apple. It was Dionysus. Yes. It was truly a big deal; that's why there's never mention of him. Court scandal of the first order. Believe me. Dionysus dropped the apple and I picked it up. He won the race. For that, I have suffered. Painfully. But, what you're wondering, I know, is Semele's role. Well. Semele stood on the sidelines and cheered Dionysus along. 
Can you imagine such betrayal from one of your own kind? Never mind that Dionysus was her son. Actually, Chasquis is her son, too. Few people know about Dionysus' twin. When he was born, the Athenians saw he was destined for athletic prowess. He was taken to join the relay runners between Bolivia and Ecuador and not until my fateful race did he return to Greece. Curiously, it was not Chasquis; he didn't get on the scene until the Jasper-Banff relay. In Greece, it was Dionysus who brought me to my knees. Stopped me in mid-pace. And Semele cheered. I won't have any of those arguments about mother's sons doing no wrong. Forget it. Dionysus screwed me. That is not funny.

So here we are in 1989 in Canada, and I'm thinking, 'If I can only get even with Semele ...'

Please do not make excuses. I know this is not the Semele of Athens. I know they are twins only in name.

In the meantime, I must nudge Linschi to create. You know how negligent she can be. Right at the moment, however, the prognosis for productive creation is very positive. She sits at the computer, typing on the keyboard, lickety-split, for all she's worth. Earlier, she called the computer repair man because the printer stopped cold, refusing to print. It signals, 'Alarm' every time she turns it on. A very recent development. In fact, it began when she came back from the university, remember, when she almost pulverized the student exiting the Humanities Centre. As soon as she realized neither a new ribbon nor straightening the paper would rectify the problem, she called the seviceman. Such efficiency! Unusual for my Linschi. I suspect that she is very serious about getting words on paper.

Ah! Ah! I detect Linschi's imagination brewing. Swirling Semele closer and closer to me. A plot evolves.

'Semele, my darling!' I whisper in her ear. 'Linschi has a big surprise for us, darling.'

To my utter dismay, the doorbell interrupts and Semele passes out of subjectivity like a fading image on a photographer's negative.

Linschi jumps to her feet, leaving the words on the screen.

I get right behind her eyeball as she squints through the peep hole. Oh, oh. He has those certain attributes I have learned to recognize.

Linschi opens the door. Smiles graciously.

He is tall. He has good feet. Feet, I can see, which could outrun mine. 


\section{Atalanta Jolts Free $\cdot 47$}

'Now, now, now. Atalanta! What is this? Atalanta, you mustn't forget the race! What kind of subject are you? Atalanta!' She scolds me. I must not get carried away.

' $\mathrm{I}$ ' $\mathrm{d}$ like this printer fixed immediately.' There is not patience at all in her voice. Strictly business. She takes him to the machine and points out the problem. Insists on demonstrating how it persistently sounds its alarm.

I glance down at his foot. Oh, my! The arch, the curve of the Achilles tendon, the spread of the toes! Can I trigger Linschi's thoughts to plot me into a race, a race with this foot? Have I strength after all these centuries to maintain my subjectivity, to be Atalanta and trip that foot? Finally, have I the strength to resist the golden apple? 